\title{
OSL DATES AND HEAVY MINERAL ANALYSIS OF UPPER QUATERNARY SEDIMENTS FROM THE VALLEYS OF THE ÉR AND BERETTYÓ RIVERS
}

\author{
EDIT THAMÓ-BOZSÓ ${ }^{1}$, ÁRPÁD MAGYARI ${ }^{1}$, ATTILA NAGY ${ }^{2}$, ZOLTÁN UNGER ${ }^{1}$ \\ and ZSOLT KERCSMÁR ${ }^{1}$ \\ ${ }^{1}$ Geological Institute of Hungary, \\ Stefánia út 14, 1143 Budapest, Hungary \\ ${ }^{2}$ Eötvös Loránd Geophysical Institute of Hungary, \\ Homonna utca 1, 1118 Budapest, Hungary
}

\begin{abstract}
The study of the evolution of the river network in the Great Hungarian Plain has been based on sedimentological, neotectonical, morphological investigations, heavy mineral analysis and complementary OSL dating. The study area extends from the Körös sub-basin into the Ér and Berettyó river valleys which are situated northeast from the subsiding basin and northwest from the uplifting Apuseni Mountains.

The OSL ages provide evidence that a large river run in the Ér-valley at least from $46 \pm 4$ to $39 \pm 4 \mathrm{ka}$. It deposited garnet and magnetite-ilmenite-rich sediments, similar to the recent Berettyó, Ér and SebesKörös rivers and less intensive the modern Tisza river. These sediments originated from the nearly located metamorphic and Neogene volcanic rocks and contain some reworked older clastic sedimentary rocks from the northern part of the Apuseni Mountains. These OSL ages fit the active tectonic phase of the Érmellék depression. Loess is 49-47, 44, 39 and 25 ka old and aeolian sands 10 to 9 ka were dated. Their heavy mineral composition and that of fluvial sands is similar.
\end{abstract}

Keywords: OSL dating on quartz, heavy mineral analysis, river network, Érmellék, Great Hungarian Plain.

\section{INTRODUCTION}

To study the evolution of the river network of the Great Hungarian Plain we analysed Upper Quaternary sediments in the Érmellék region. The main areas were the valleys of the Ér- and Berettyó rivers, which are located east from the Great Hungarian Plain and northwest from the Apuseni Mountains (Fig. 1). These rivers carry sediments into the Körös sub-basin. High-resolution cyclostratigraphical and palaeoclimate analyses indicated that the 420-460 $\mathrm{m}$ thick Pleistocene fluvial succession in the Körös sub-basin was continuously deposited under net subsiding conditions during the Pleistocene, controlled by the climate and tectonic movements (ThamóBozsó et al., 2002; Nádor et al., 2003 and 2007). The evolution of the river network of this sub-basin during the

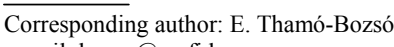

e-mail: bozso@mafi.hu

ISSN 1897-1695 (online), 1733-8387 (print) (C) 2007 GADAM Centre, Institute of Physics, Silesian University of Technology.

All rights reserved.
Late Pleistocene was investigated by sedimentological, morphological, tectonic methods, and heavy mineral analysis. A detailed chronological framework (Nádor et al., 2007; Thamó-Bozsó et al., 2007) was elaborated applying optically stimulated luminescence (OSL) dating on quartz. The interpretation of seismic profiles, the field measurements of the neotectonic activity, and the variability of the thickness of sediments in the Körös subbasin revealed that the river development was largely controlled by the subsidence along the Érmellék depression until 14 to $16 \mathrm{ka}$, and by uplift of the southeastern part of the catchment area (Nádor et al., 2007). In order to extend these studies to the development of the margin of the basin we studied the sediments in the valleys of Ér and Berettyó rivers, northeast from the Körös sub-basin. There, natural outcrops allow to analyse Upper Quaternary sediments, neotectonic features and morphological elements. 


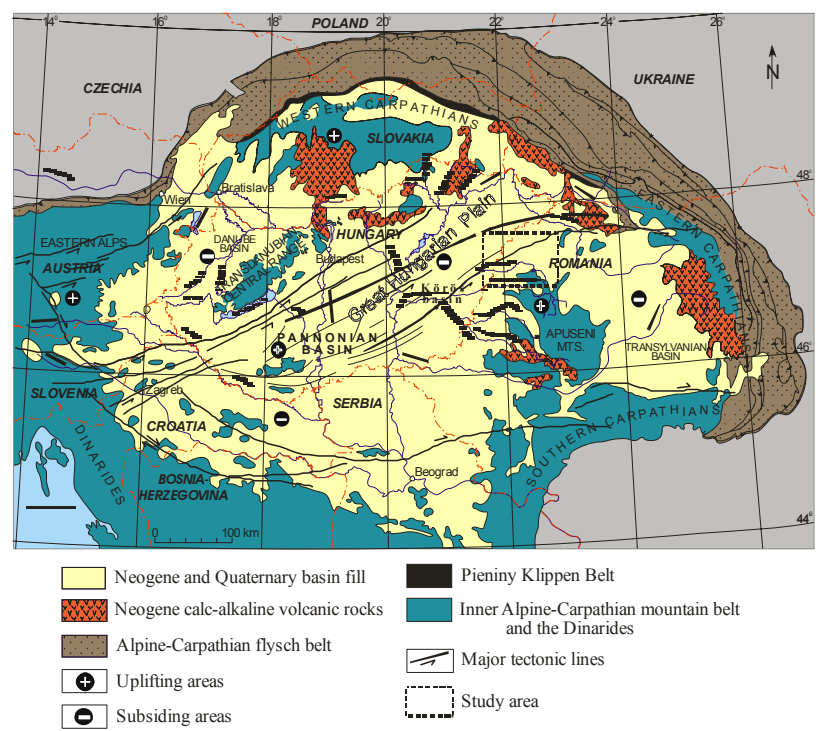

Fig. 1. Study area and geological surroundings (after Bada and Horváth, 2001).

\section{STUDY AREA}

The valleys of the Ér and Berettyó rivers are situated in the norteastern part of the Pannonian Basin (Fig. 1). The large intermountain Pannonian Basin, surrounded by the Alps, Carpathians and Dinarides, formed during the Early and Middle Miocene by back-arc style rifting, coeval with the late stages of thrusting of the Carpathian belt (Royden and Horváth, 1988). From the Late Miocene onwards post-rift thermal subsidences initiated the isolation of the Pannonian Basin from the Paratethys and the depression was occupied by the Lake Pannon. The lake was filled up by large fluvial-dominated delta systems prograded from NW to NE during the Late MiocenePliocene and filled up with alluvial sediments (Royden and Horváth, 1988; Juhász, 1994; Magyar et al., 1999). About 6 Ma ago NW-SE and N-S compression started and caused the uplift of the marginal Carpathian Belt, Apuseni Mountains, North Hungarian Range and Transdanubia, and subsidence of the basins which were progressively filled up mainly by sediments transported by the ancestors of the Danube and Tisza rivers and their tributaries. The differential uplift and subsidence rates in the basin caused a complex evolution of the drainage network.

The study area is located northeast from the subsiding Körös sub-basin and northwest from the uplifting Apuseni Mountains (Fig. 1). It has a ENE-WSW striking hilly morphology about $110-210 \mathrm{~m}$ above sea level (Fig. 2). The NW part of it with the Érmellék region is at a lower position; the SE section with the Szilágyság region is more elevated. The Ér River is only $40 \mathrm{~km}$ long, 4-7 m wide, joins the Berettyó River, which is $203 \mathrm{~km}$ long and has a drainage area of about $6100 \mathrm{~km}^{2}$. The Berettyó River flows along the southern part of the Érmellék depression and further into the Sebes Körös River in Hungary. The latter is $209 \mathrm{~km}$ long and has a catchment area of about $2800 \mathrm{~km}^{2}$, it merges with the Körös

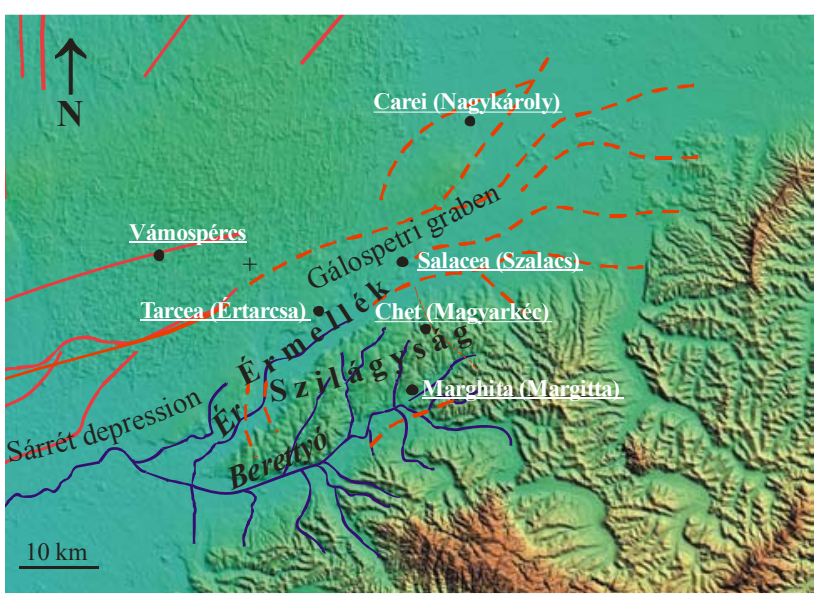

Fig. 2. Location of the studied sections and the main Quaternary faults (cut from DEM map of Timár et al., 2003).

rivers and continue as Hármas-Körös River, the tributary of Tisza River (Fig. 1). The Ér, Berettyó and SebesKörös rivers originate in the northern part of the Apuseni Mountains.

Érmellék is a seismoactive region. The last two earthquakes occurred in 1829 and 1834 with estimated magnitude of 5.5 and 7.1, respectively (Réthly, 1952; Szeidovitz, 2000). There is a tectonic zone between the hilly region of Szilágyság and the Great Hungarian Plain in the Sárrét depression and the Gálospetri graben (Fig. 2)

According to the sedimentological and paleontological data, the Quaternary sediments are 150-300 m thick on the eastern part of the Great Hungrian Plain. They are gradually thinning towards the east (Franyó, 1992; Rónai, 1985; T,enu, 1981). In the Érmellék region 15-20 m thick Pleistocene sections containing fluvial sand and gravel, loess and paleosoils are present. In the loess sections brown forest type paleosoils occur in the lower position and forest steppe or chernozem type paleosoils in the higher position. The loess is intercalated with alluvial sand and flood plain silty clay. Pleistocene sediments are overlain by a few meters thick Holocene re-deposited loess, silty sand, silty clay, aeolian sand, peat and a recent soil of the forest steppe type. On the modern surface of the study area fluvial and aeolian sands dominate on the lower horizon (near the rivers and their neighbourhood), and loess on the more elevated places.

\section{SAMPLES AND STUDY METHODS}

Based on sedimentological and tectonic field observations, samples of loess, fluvial and aeolian sand were collected from 1.2 to $4.5 \mathrm{~m}$ below the recent surface from six outcrops for optically stimulated luminescence (OSL) dating and heavy mineral analysis (Figs 2 and 3). Quartz was extracted from the grain size fraction 100-160 $\mu \mathrm{m}$ using $\mathrm{H}_{2} \mathrm{O}_{2}$ to remove the organic constituents, and $10 \%$ $\mathrm{HCl}$ to dissolve carbonates. The samples contained very small amounts of organic material, and only the loess samples contained some carbonate. An aqueous solution of sodium polytungstate was used for density separation of the quartz-rich fraction. Then it was etched with $40 \%$ HF for 60 minutes to remove any remaining feldspars and 
WSW

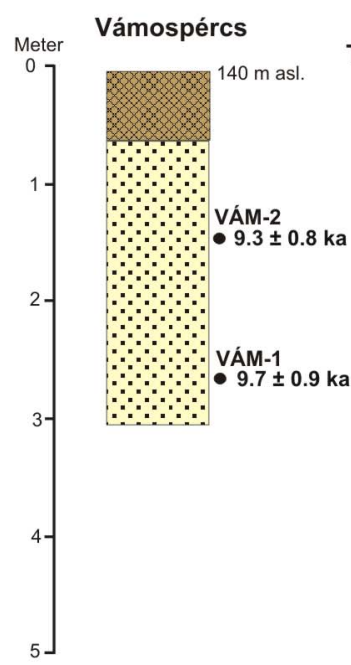

Chet (Magyarkéc)

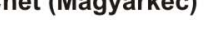

ENE

Carei (Nagykároly)

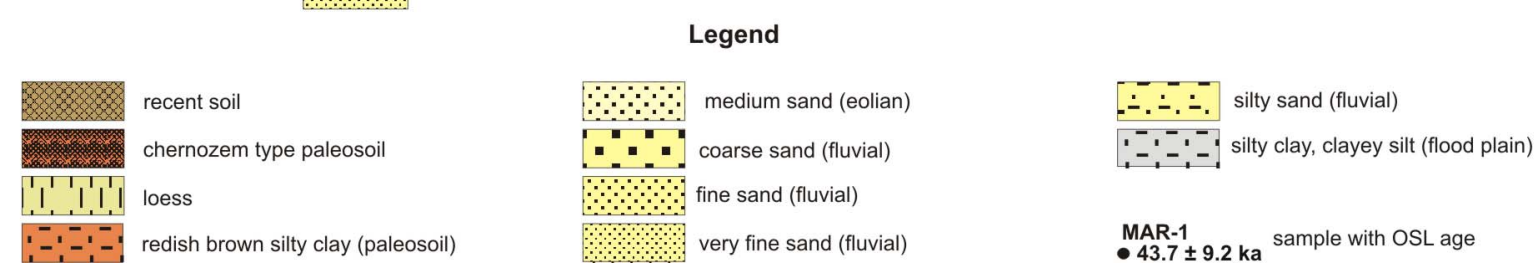

Fig. 3. Lithology of the studied sections and OSL ages (Hungarian names of the villages are given in brackets).

the outer $\sim 10 \mu \mathrm{m}$ layer from the quartz grains, which absorbed a dose from alpha radiation (Aitken, 1985 and 1998). High mica content of the quartz fraction of some loess samples was successfully separated by rolling the grains on paper. A monolayer of clean quartz grains were mounted on stainless-steel discs with $8 \mathrm{~mm}$ diameter using silicone spray.

OSL measurements were made using a Risø TL/OSL DA-15C/D automated reader with a calibrated ${ }^{90} \mathrm{Sr} /{ }^{90} \mathrm{Y}$ beta source, delivering about $0.124 \mathrm{~Gy} / \mathrm{s}$ to the disk. The luminescence purity of the quartz extracts was checked using infra-red stimulation. To empty the shallow traps, which may be unstable during the burial period of the sediment, a $260^{\circ} \mathrm{C}$ preheat temperature was applied. Optical stimulation was performed by blue light-emitting diodes (LEDs) for $40 \mathrm{~s}$ at $125^{\circ} \mathrm{C}$. Equivalent doses were estimated using the Single-Aliquot Regenerative-dose (SAR) protocol (Murray and Wintle, 2000 and 2003; Murray and Olley, 2002; Wintley and Murray, 2006). Dose recovery tests, the dose response grow curve and the thermal transfer test were carried out for each sample. A preheat plateau test was done on one sample from each outcrop. In most cases, the equivalent dose $\left(D_{e}\right)$ was derived from 23-29 aliquots per sample. In the case of three loess samples only 6,9 and 16 aliquots per sample were available due to the low quartz fraction. The dose rates were calculated using the conversion factors by Adamiec and Aitken (1998) based on laboratory highresolution gamma spectrometry analyses (Canberra GC3020) of about 0.7-1.0 kg bulk sediment which surrounded the OSL samples.

Microscopic study was applied to trace the origin of the sediments. It was performed on the same samples as were subject of OSL measurements using a stereo and polarising microscope. Heavy minerals were separated from the $100-200 \mu \mathrm{m}$ grain size fraction by bromoform using centrifuge.

\section{RESULTS}

\section{Sedimentological and tectonic field observations}

In the studied sections sandy sediments dominate at Vámospércs, Tarcea (Értarcsa), and Carei (Nagykároly) (Fig. 3). There are at least 2-3 m thick coarse or fine grained fluvial sand bodies, which are partly cross laminated. At Carei (Nagykároly) the sand is covered by $0.6 \mathrm{~m}$ thick brown or reddish bown clay (paleosoil), which forms a thin layer also in the sand, and several decimeters thick loess. At Tarcea (Értarcsa) the fluvial sand is overlain by about $1.5 \mathrm{~m}$ thick silty clay and clayey silt floodplain sediments, a chernozem type paleosoil and some loess. Far from the hills, at Vámospércs, there is aeolian reworked fluvial sand which is partly cross laminated.

Southeast in the hilly part of the Érmellék region 1.0-3.7 $\mathrm{m}$ thick pale yellow or brownish yellow loess bodies outcrop in sections at Salacea (Szalacs), Chet (Magyarkécz) and Marghita (Margitta). They are alternated with, or are covered by 0.1-1.0 m reddish brown silty clay layers (paleosoils), which frequently contain $\mathrm{MnO}$ pizolites and limonite concretions.

The micro- and morphotectonic measurements in the Szilágyság region provide evidence for two phases of deformations. The older was generated by a NE-SW compression, which caused left lateral strike slips. The younger was generated by the WNW-ESE compression and caused right lateral strike slips (transpression), which seem to be active till now. The network of the tectonic lines is very similar to those, analysed from seismic sec- 
tions of the Körös sub-basin. More details are given by Magyari et al. (in press).

\section{OSL dating}

Various tests have confirmed that the quartz samples are suitable for OSL age determination. Applying the SAR protocol a known laboratory dose administered to these samples were accurately measured. Dose response growth curves showed that measurements are possible up to the applied $320 \mathrm{~Gy}$. Quartz in the loess samples is more saturated than in the sands, except the loess at Chet (Magyarkécz). Based on the results of the preheat plateau tests, $260^{\circ} \mathrm{C}$ preheat temperature was used. It was also found that thermal transfer was negligible in the measured samples. Most samples have delivered symmetric and narrow frequency histograms of the equivalent doses apart of the MAR-1 and MAR-2 loess samples.

The equivalent doses $\left(D_{e}\right)$ of the samples have wide range between 8 and 103 Gy (Table 1). The loess samples were more radioactive (14.5 ppm Th; $3.2 \mathrm{ppm} \mathrm{U}$; $0.6 \% \mathrm{~K}$ in average) compared to the sands (3.8 ppm $\mathrm{Th}$; $1.0 \mathrm{ppm} \mathrm{U} ; 0.3 \% \mathrm{~K})$. Hence, the loess samples have higher dose rates $(1.9-2.3 \mathrm{~Gy} / \mathrm{ka})$ than the sands (0.8-1.3 Gy/ka).

The water content of the sediments at the time of sampling was in the range of 2 to 23 dry weight $\%$. The laboratory saturated water content ranged from 20 and $43 \%$ dry weight. Samples were collected above the recent ground water level. The assumed water content for the time span of burial was taken as mean of the current and the saturated water content. The estimated OSL ages range from 9 to $49 \mathrm{ka}$ (Table 1). The ages of KÉ and MAR loess samples are less reliable than those of the other sediments (age of MAR-1 has large standard deviation) due to the smaller number of the measured aliquots.

The new OSL ages are stratigraphically consistent within their sections. Loess and aeolian sands are usually well bleached during the aeolian transport and before deposition resetting the OSL signal (e.g. Duller, 2004). Although the optical bleaching of fluvial sediments depends on the fluvial transport distance (Stokes et al., 2001) the transport lengths of 20-40 km was sufficient as confirmed by the symmetric and narrow frequency histograms of the equivalent doses of these fluvial samples.

\section{Microscopic study}

The largest detrital grains in the studied sediments are $1 \mathrm{~mm}$. Quartz dominates among the grains of $>0.2 \mathrm{~mm}$, which contain some quartzite and rock fragments originating from metamorphic, volcanic, and older sedimentary rocks (e.g. red sandstone). Feldspar, amphibole, pyroxene and opaque minerals are very rare. Limonite and manganese-oxide concretions, rhizoconcretions and cemented grains are more frequent in the loess samples than in the sands.

In the 0.1 to $0.2 \mathrm{~mm}$ fine-grained sand fraction of the samples usually quartz is the most frequent mineral. Muscovite and altered biotite dominate in the MAR and SZA loess samples. There are a few multiple-twinned acidic-neutral plagioclases (MAR, VÁM), orthoclase and cross-hatched twinning grains of microcline (SZA), several rock fragments and altered minerals, too.

Quartz grains are usually subrounded, some of them are well-rounded and have polished surface showing the effect of aeolian reworking. The most well rounded grains are found in the VÁM, ÉRTA (and SZA) samples.

The heavy mineral content in the fine grained sand fraction ranges from 0.3 to 2.8 weight $\%$ (Table 2). Most of the loess samples contain less heavy minerals (0.3-0.9 weight $\%)$ than sands (1.0-2.8 weight\%). Usually garnet and magnetite-ilmenite are the most frequent detrital heavy minerals in the samples. Amphibole and pyroxene are also common. Sometimes biotite (MAR-1), sometimes amphibole dominates (MAR-2). Chlorite, tourmaline (shorl), and staurolite are less frequent. Rutile, zircon, apatite, monazite, epidote, kainite, sillimanite, andalusite and zoisite are rare. Secondary minerals are limonite, manganese-oxide, leucoxene and altered minerals. Garnets are mainly pale pink or colourless, chlorite is usually pale green, biotite is partly altered to chlorite. Amphiboles as hornblende presents in each sample, oxihornblende and actinolite-tremolite are rare. Hornblende sometimes has rugged termination. Ortho- and/or clinopyroxenes, first of all hypersthene, ferrohypersthene and augite were also identified in most of the sediments. There are hypersthene and augite grains with "hacksaw” terminations too.

Comparing the different samples, loess sediments contain more mica and altered minerals than sands, while the fluvial sands have higher garnet content. SZA and KÉ loess samples have a similar magnetite-ilmenite and

Table 1. Results of quartz OSL dating ( $n$ - number of measured aliquots, w.c. - assumed water content).

\begin{tabular}{|c|c|c|c|c|c|c|c|c|}
\hline & Sapmle & $\begin{array}{l}\text { Depth } \\
\text { (cm) }\end{array}$ & Sediment & $\mathbf{n}$ & $\begin{array}{c}\text { Equivalent dose } \\
(\mathrm{Gy})\end{array}$ & $\begin{array}{c}\text { Dose rate } \\
\text { (Gy/ka) }\end{array}$ & $\begin{array}{l}\text { w. C. } \\
(w \%)\end{array}$ & $\begin{array}{l}\text { OSL age } \\
\text { (ka) }\end{array}$ \\
\hline SZA-2 & Salacea (Szalacs) & 200 & loess & 23 & $102.60 \pm 4.30$ & $2.20 \pm 0.15$ & 23.5 & $46.70 \pm 3.87$ \\
\hline SZA-1 & Salacea (Szalacs) & 380 & loess & 23 & $90.32 \pm 6.96$ & $1.86 \pm 0.13$ & 29.6 & $48.47 \pm 5.09$ \\
\hline KÉ-1 & Chet (Magyarkéc) & 160 & loess & 9 & $51.65 \pm 4.89$ & $2.05 \pm 0.14$ & 32.8 & $25.20 \pm 2.97$ \\
\hline ÉRTA-2 & Tarcea (Értarcsa) & 320 & coarse-medium grained sand & 25 & $35.16 \pm 2.21$ & $0.87 \pm 0.06$ & 11.6 & $40.36 \pm 3.84$ \\
\hline ÉRTA-1 & Tarcea (Értarcsa) & 450 & medium grained sand & 24 & $39.93 \pm 2.16$ & $0.95 \pm 0.07$ & 13.3 & $42.09 \pm 3.80$ \\
\hline MAR-2 & Marghita (Margitta) & 120 & loess & 16 & $78.03 \pm 7.56$ & $2.00 \pm 0.14$ & 25.2 & $38.95 \pm 4.66$ \\
\hline MAR-1 & Marghita (Margitta) & 280 & loess & 6 & $99.80 \pm 19.64$ & $2.28 \pm 0.16$ & 24.7 & $43.74 \pm 9.17$ \\
\hline VÁM-2 & Vámospércs & 140 & medium grained sand & 24 & $7.93 \pm 0.45$ & $0.86 \pm 0.06$ & 12.7 & $9.27 \pm 0.82$ \\
\hline VÁM-1 & Vámospércs & 260 & medium grained sand & 27 & $7.82 \pm 0.44$ & $0.81 \pm 0.06$ & 11.1 & $9.67 \pm 0.87$ \\
\hline NA-2 & Carei (Nagykároly) & 160 & medium grained sand & 25 & $49.652 \pm 4.056$ & $1.27 \pm 0.08$ & 14.5 & $39.20 \pm 4.20$ \\
\hline NA-1 & Carei (Nagykároly) & 250 & medium grained sand & 29 & $36.365 \pm 2.031$ & $0.80 \pm 0.05$ & 12.1 & $45.48 \pm 4.10$ \\
\hline
\end{tabular}


Table 2. Results of heavy mineral analysis (\% data based on point counting, $x$ - less than $0.5 \%$ ).

\begin{tabular}{|c|c|c|c|c|c|c|c|c|c|c|c|}
\hline Sample & SZA-2 & SZA-1 & KÉ-1 & ÉRTA-2 & ÉRTA-1 & MAR-2 & MAR-1 & VÁM-2 & VÁM-1 & NA-2 & NA-1 \\
\hline heavy mineral content $(\mathrm{w} \%)$ & 0.55 & 0.92 & 2.12 & 1.29 & 1.81 & 0.57 & 0.26 & 1.66 & 1.92 & 1.01 & 2.82 \\
\hline hornblende & 12.9 & 11.6 & 3.7 & 12.4 & 9.1 & 24.5 & 5.9 & 17.6 & 9.9 & 10.8 & 18.2 \\
\hline oxi-hornblende & 1.6 & 1.5 & $\mathrm{x}$ & 0.6 & 1.9 & & & 1.5 & $x$ & & \\
\hline actinolite-tremolite & 1.6 & $\mathrm{x}$ & $\mathrm{x}$ & & $x$ & $x$ & $x$ & & & & \\
\hline other amphibole & 3.2 & 2.9 & & 1.1 & & 2.0 & & & 1.8 & & \\
\hline augite & 4.0 & 2.9 & 2.5 & 3.2 & 4.7 & $\mathrm{x}$ & $x$ & 2.9 & & 0.5 & 6.3 \\
\hline hypersthene & & 1.5 & 3.7 & 3.2 & 1.9 & 7.1 & $\mathrm{x}$ & 5.2 & 7.1 & 1.4 & 11.9 \\
\hline ferrohyperstene & 1.6 & $x$ & 1.2 & 0.6 & 1.9 & 2.0 & & 2.2 & 0.9 & 3.7 & 2.1 \\
\hline magnetite-ilmenite & 30.6 & 14.9 & 21.0 & 18.5 & 28.3 & 16.3 & 12.9 & 29.1 & 41.1 & 29.4 & 10.5 \\
\hline biotite & & $\mathrm{x}$ & 1.2 & & & & 15.8 & & & & \\
\hline altered biotite & & & 3.8 & 1.7 & & 2.0 & 22.8 & $x$ & $x$ & & \\
\hline garnet & 24.2 & 23.6 & 14.8 & 49.5 & 34.0 & 17.3 & 8.9 & 25.4 & 20.5 & 40.7 & 33.6 \\
\hline staurolite & 1.6 & 1.5 & & 0.6 & 2.5 & 1.7 & 2.0 & 3.7 & $\mathrm{x}$ & $\mathrm{x}$ & 0.7 \\
\hline epidote & $x$ & & & & 0.6 & & & & & & \\
\hline kyanite & 1.6 & & $x$ & & & $x$ & $x$ & & & $x$ & $x$ \\
\hline sillimanite & $\mathrm{x}$ & & & & & $x$ & $x$ & & $x$ & $x$ & 1.4 \\
\hline andalusite & 0.8 & $\mathrm{x}$ & & & & & & & & $x$ & \\
\hline chlorite & 2.4 & 15.0 & $x$ & $x$ & & $x$ & $x$ & $x$ & $x$ & $x$ & 0.7 \\
\hline zoisite & & 2.9 & & & $x$ & $x$ & $x$ & 2.6 & & & \\
\hline apatite & & & & $x$ & & & & & & 2.3 & $x$ \\
\hline zircon & & $x$ & $x$ & 0.6 & & & & $x$ & & & $x$ \\
\hline rutile & 2.4 & $x$ & & 1.1 & 1.9 & & $x$ & $\mathrm{x}$ & 0.9 & 0.5 & 1.4 \\
\hline tourmaline (shorl) & 3.2 & & $x$ & & 0.6 & $x$ & 2.0 & 0.8 & 1.8 & $\mathrm{x}$ & 0.7 \\
\hline monazite & 1.6 & 2.9 & $x$ & $x$ & 1.3 & & 1.0 & $x$ & 1.5 & 1.4 & 1.4 \\
\hline rock fragment & 3.2 & & & & 1.9 & 6.1 & & $\mathrm{x}$ & 6.3 & 1.4 & 5.2 \\
\hline limonite & $x$ & 2.9 & 14.8 & $x$ & & 10.2 & 19.8 & & 2.7 & & \\
\hline leukoxene & 0.8 & 5.8 & 2.5 & 1.1 & 5.0 & 4.5 & 8.9 & 4.1 & 2.0 & 5.6 & 6.1 \\
\hline altered minerals & 2.4 & 10.1 & 30.8 & 6.0 & 4.4 & 6.1 & & 5.2 & 3.6 & 2.0 & \\
\hline summa & 100.0 & 99.8 & 100.0 & 100.0 & 100.0 & 99.9 & 100.0 & 100.4 & 99.9 & 99.6 & 100.1 \\
\hline
\end{tabular}

garnet-rich heavy mineral composition as the sand samples in the other sections. But the MAR loess is very different, containing much amphibole or biotite. Sands contain more well-rounded, polished grains than the loess, first of all the VÁM and ÉRTA samples.

The quantitative detrital heavy mineral composition of the samples was compared to each other and to that of the recent rivers sediments in the area using cluster analysis (Thamó-Bozsó et al. 2007, Thamó-Bozsó and ÓKovács, 2007). The results provide evidence, that the samples ÉRTA-1, ÉRTA-2 and NA-2 of fluvial sands are very similar to each other because of their high garnet content. The samples SZA-1, SZA-2, and KÉ of loess and the samples VÁM-1 and VÁM-2 of aeolian sands are also very similar due to the high magnetite-ilmenite and garnet content. These samples are related with the samples NA-1 of fluvial sand and MAR-2 of loess, which contain more amphibole than the other samples. The lower MAR1 loess sample is different because of a high biotite content. Despite the differencies, the studied sediments are most similar to the sediments of recent Berettyó, Ér and Sebes-Körös rivers. The three samples NA-1, SZA-1 and MAR-2 also show similarities to the Tisza River sediments.

\section{DISCUSSION}

It was recognised at the beginning of the $19^{\text {th }}$ century, that the ancestral river network in the Hungarian Plain was different from the present one. This was concluded from the abandoned fluvial channels and alluvial fans (Somogyi, 1961 and references therein). Based on sedimentological and hydrogeological studies, palaeo-river network reconstructions were drawn (e.g. Sümeghy, 1951; Urbancsek, 1960; Somogyi, 1961; Borsy, 1989; Borsy et al., 1989; Mike, 1991; Gábris, 1994; Neppel et al., 1999). Recently ancient river patterns of the Great Hungarian Plain were studied also by morphological and tectonic methods, radiocarbon and OSL age dating (e.g. Gábris and Nagy, 2005; Timár et al., 2005; Thamó-Bozsó et al., 2007; Nádor et al. 2007; Gábris and Nádor, in press).

Reconstructions provide evidence that the palaeoTisza flowed south of its present course, most probable in the valley of the modern Ér River. It collected waters of rivers approaching from the north, east and southeast (Sümeghy, 1951; Urbancsek, 1960; Borsy, 1989). Somogyi (1961) supposed that the Tisza River and its tributaries formed their recent course during the Holocene as result of tectonic movements. Borsy et al. (1989) argued that this happened only 4500 years ago. In contrary Molnár (1997) suggested that the Tisza River gradually shifted his course towards the west already in the GünzMindel interglacial. Gábris (1998 and 2002) claims that the much larger palaeo-Tisza River run in the southwestern part of the Érmellék depression, where the modern Berettyó River flows. Based on the study of Late Quaternary dynamics of the Tisza River, Timár et al. (2005) suggest that its major avulsion event happened about 16-18 ka ago. Our OSL ages show that the modern rivers 
in the Körös sub-basin formed their present courses only during the last $10 \mathrm{ka}$ (Thamó-Bozsó et al., 2007). The river development in Körös sub-basin was largely controlled by the subsidence in the Érmellék depression until 14 to $16 \mathrm{ka}$ along the Dévaványa-Szarvas fault zone, and by the uplift of the southeastern part of the catchment area (Nádor et al., 2007). Our new data in this study provide further information on the development of the Érand Berettyó river valleys and the neotectonic control.

The palaeochannel of a large river in the Ér valley can be seen on the Digital Elevation Model (DEM) and satellite maps (e.g. GoogleErth) and on airborne fotographs. It is an at least $10 \mathrm{~km}$ wide NE-SW straight and bend valley. The sedimentological characteristics of the fluvial sands in the study area (thickness, stratification, grain size) suggests that in the past a much larger river was in the Ér River valley than today.

The OSL ages of the loess samples are 47-49, 44, 39, and $25 \mathrm{ka}$. Fluvial sands deposited between 46 and $39 \mathrm{ka}$, aeolian sands about 9-10 ka. According to earlier determined OSL and TL ages, similar 37-50 ka old loesspaleosoil successions were found on the Transdanubian area of Hungary (e.g. Novothny et al., 2002; Novothny et al., in press). 37 or $45 \mathrm{ka}$ old fluvial sands also occur in the Körös sub-basin (Thamó-Bozsó et al., 2007). The aeolian sand formation at 9-10 ka is confirmed by luminescence ages e.g. near the Danube (Újházy, 2002; Újházy et al., 2003) providing evidence for a sand movement preferentially during the early Holocene.

The fluvial sands in the study area are the sediments of a large river, which occupied the Ér Valley at least from $46 \pm 4$ to $39 \pm 4 \mathrm{ka}$. These ages date an active tectonic phase of the Érmellék region, which belongs to the older neotectonic movements (NE-SW compression) identified by micro- and morphotectonic measurements.

Heavy mineral studies of the Quaternary sediments in the Great Hungarian Plain also helped to reconstruct the ancient river network. According to the lithology of the catchment areas of the recent rivers which probably drained the study area we conclude that minerals of Neogene andesites, rhyolites and tuffs of the Inner Carpathian Volcanics are characteristic in the sediments of the Bodrog and Szamos river and of the upper section of the Tisza River. These sediments also contain more pyroxenes and hornblende than others. Low-, medium- and high-grade metamorphic rocks dominate in the catchment area of the Sebes-Körös, Berettyó and Ér rivers, which have a high garnet and magnetite content.

The garnet and magnetite-ilmenite-rich heavy mineral composition of the fluvial sands at the Carei (Nagykároly) and Tarcea (Értarcsa) indicate, that they originated from nearby metamorphic and Neogene volcanic rocks and recycled old clastic sedimentary rocks, similar to sediments of recent rivers on the northern part of the Apuseni Mountains. Fluvial sands are present in the Great Hungarian Plain with similar ages and more or less similar heavy mineral composition. The aeolian sands at Vámospércs and the loess samples at Salacea (Szalacs) and Chet (Magyarkéc) have a similar mineral composition than the fluvial sands. This indicates that they probably were reworked from the adjacent fluvial sediments and blown out from river flood plains by winds. The different biotite or amphibole-rich loess samples at Marghita (Margitta) reflect that they derived from other valley, the Berettyó river valley, where the mineral composition of the fluvial sediments was different.

\section{CONCLUSIONS}

Our study on the evolution of the river network in the Great Hungarian Plain extended the already investigated area of the Körös sub-basin with the Ér and Berettyó rivers valley, which is situated northeast from the subsiding basin and northwest from the uplifting Apuseni Mountains.

The new OSL ages indicate that loess deposited at Salacea (Szalacs) in the central part of the Érmellék region about 47-49 ka ago. Some younger fluvial sands with ages of 46 and 42 to $39 \mathrm{ka}$ were found at Carei (Nagykároly) and Tarcea (Értarcsa). At the same time between 44 and 39 ka loess deposited at Marghita (Margitta) and at $25 \mathrm{ka}$ in Chet (Magyarkéc). Far from the hilly area at Vámospércs aeolian sand from reworked fluvial sediments of the Érmellék region accumulated 9-10 ka ago.

Our results provided evidence that the river which flowed in the Érmellék region at least from $46 \pm 4$ to $39 \pm 4$ ka was much larger than the present Ér River. Its garnet and magnetite-ilmenite-rich sediments originated from adjacent metamorphic and Neogene volcanic rocks and reworked old clastic sedimentary rocks. This large river drained the northern part of the Apuseni Mountains, because it has a similar heavy mineral composition than the recent Berettyó, Ér and Sebes-Körös rivers, and partly the modern Tisza River. The aeolian sands and the loesses are probably reworked adjacent fluvial sediments, blown out from river flood plains by winds.

The ages of the fluvial sands of a large river in the study area date the active tectonic phase of the Érmellék depression.

\section{ACKNOWLEDGEMENTS}

This research was supported by the Hungarian National Research Fund (OTKA T 046307). Help from Péter Kovács-Pálffy and discussions with Annamária Nádor are gratefully acknowledged.

\section{REFERENCES}

Adamiec G and Aitken M, 1998. Dose-rate conversion factors: update. Ancient TL 16: 37-50.

Aitken MJ, 1985. Thermoluminescence Dating. London, Academic Press: 359pp.

Aitken MJ, 1998. An Introduction to Optical Dating. The Dating of Quaternary Sediments by the Use of Photon-stimulated Luminescence. Oxford, Oxford University Press: 267pp.

Bada G and Horváth F, 2001. On the structure and tectonic evolution of the Pannonian basin and surrounding orogens. Acta Geologica Hungarica 44: 301-327.

Borsy Z, 1989. Az Alföld hordalékkúpjainak negyedidőszaki fejlődéstörténete (Quaternary evolution of the alluvial fans of the Great Hungarian Plain). Földrajzi Értesitö 38: 211-224 (in Hungarian).

Borsy Z, Félegyházi E and Csongor É, 1989. A Bodrogköz kialakulása és vízhálózatának változásai (The development of the Bodrogköz 
and its fluvial network). Alföldi Tanulmányok 13: 65-82 (in Hungarian).

Duller GAT, 2004. Luminescence dating of Quaternary sediments: recent developments. Journal of Quaternary Science 19(2): 183192, DOI 10.1002/jqs.809.

Franyó F, 1992. Magyarország 1:200 000-es kvarter talpmélység térképe (Deepness map of the bottom of Quaternary in Hungary, 1:200 000). National Geological and Geophysical Archive, Budapest (manuscript, in Hungarian).

Gábris Gy, 1994. Pleistocene evolution of the Danube in the Carpathian Basin. Terra nova 6(5): 495-501, DOI 10.1111/j.13653121.1994.tb00893.x.

Gábris Gy, 1998. Late Glacial and Post Glacial development of drainage network and the paleohydrology in the Great Hungarian Plain. In: Bassa L and Kertész Á, eds., Windows on Hungarian Geography. Budapest, Akadémiai kiadó: 23-36.

Gábris Gy, 2002. A Tisza helyváltozásai (The shifting Tisza River.) In: Mészáros R, Schweitzer F and Tóth J, eds., Jakucs László, a tudós, $a z$ ismeretterjesztő és a müvész. Pécs, Magyar Tudományos Akadémia Földrajzi Kutatóintézet, Pécsi Tudományegyetem: 91105 .

Gábris Gy and Nádor A, in press. Long-term fluvial archives in Hungary: response of the Danube and Tisza rivers to tectonic movements and climatic changes during the Quaternary. Quaternary Science Reviews.

Gábris Gy and Nagy B, 2005. Climate and tectonically controlled river style changes on the Sajó-Hernád alluvial fan (Hungary). In: Harvey AM, Mather AE and Stokes M, eds., Alluvial Fans: Geomorphology, Sedimentology, Dynamics. London, Geological Society, Special Publications 251: 61-67.

Juhász Gy, 1994. Magyarországi neogén medencerészek pannóniai s. 1. üledéksorának összehasonlító elemzése (Comparision of the sedimentary sequences in Late Neogene sub-basins in the Pannonian Basin, Hungary). Földtani Közlöny 124: 341-365 (in Hungarian).

Magyar I, Geary DH and Müller P, 1999. Paleogeographic evolution of the Late Miocene Lake Pannon in Central Europe. Palaeogeography, Palaeoclimatology, Palaeoecology 147(3-4): 151-167, DOI 10.1016/S0031-0182(98)00155-2.

Magyari Á, Kercsmár Zs, Unger Z and Thamó-Bozsó E, in press. Neotectonic investigations of the Érmelék region (NE Pannonian Basin). Magyar Állami Földtani Intézet Évi Jelentése 2006.

Mike K, 1991. Magyarország ősvizrajza és felszini vizeinek története (Paleo river network of Hungary and history of our rivers). Budapest, AQUA kiadó: 698pp (in Hungarian).

Molnár B, 1997. The geological makeup and evolution history of Great Hungarian Plain. Hydro-Petro-Geology and Hungary. Manuscript, Budapest, MFT: 1-57.

Murray AS and Olley JM, 2002. Precision and accuracy in the optically stimulated luminescence dating of sedimentary quartz. Geochronometria 21 : 1-16.

Murray AS and Wintle AG, 2000. Luminescence dating of quartz using an improved single-aliquot regenerative-dose protocol. Radiation Measurements 32(1): 57-73, DOI 10.1016/S1350-4487(99)00253$\mathrm{X}$.

Murray AS and Wintle AG, 2003. The single aliquot regenerative dose protocol: potential for improvements in reliability. Radiation Measurements 37(4-5): 377-381, DOI 10.1016/S13504487(03)00053-2.

Nádor A, Lantos M, Tóth-Makk Á and Thamó-Bozsó E, 2003. Milankovitch-scale multi-proxy records for the fluvial sediments of the last 2.6 Ma from the Pannonian Basin, Hungary. Quaternary Science Reviews 22(20): 2157-2175, DOI 10.1016/S02773791(03)00134-3.

Nádor A, Thamó-Bozsó E, Magyari Á and Babinszki E, 2007. Fluvial responses to tectonics and climate change during the Late Weichselian in the eastern part of the Pannonian basin (Hungary). Sedimentary Geology, DOI 10.1016/j.sedgeo.2007.03.001.

Neppel F, Somogyi S and Domokos M, 1999. Palaeogeography of the Danube and its catchment. A hydrographic monograph 5. Budapest: $62 \mathrm{pp}$.
Novothny A, Horváth E and Frechen M, 2002. The loess profile at Albertirsa, Hungary - improvements in loess stratigraphy by luminescence dating. Quaternary International 95-96: 155-163, DOI 10.1016/S1040-6182(02)00036-8.

Novothny A, Frechen M, Horvath E, Bradak B and Oches E, in press. Luminescence and amino acid racemization chronology of the loess-paleosol sequence at Süttő, Hungary. Quaternary International.

Réthly, 1952. A Kárpátmedencék földrengései 455-1918 (Earthquakes in the Carpathian basin 455-1918). Budapest, Akadémiai Kiadó: $510 \mathrm{pp}$ (in Hungarian).

Rónai A, 1985. Az Alföld negyedidöszaki földtana (The Quaternary of the Great Hungarian Plain). Geologica Hungarica series Geologica 21: 446pp (in Hungarian).

Royden LH and Horváth F, 1988. The Pannonian Basin. A case study in basin evolution. AAPG Memoirs 45: 394pp.

Somogyi S, 1961. Hazánk folyóhálózatának fejlődéstörténeti vázlata (Outline of the river network evolution of Hungary). Földrajzi Közlöny 85: 25-50 (in Hungarian).

Stokes S, Bray HE and Blum MD, 2001. Optical resetting in large drainage basins; tests of zeroing assumptions using single-aliquot procedures. Quaternary Science Reviews 20(5-9): 879-885, DOI 10.1016/S0277-3791(00)00045-7.

Sümeghy J, 1951. A Tiszaszabályozás földtani vonatkozásai (Geological respects of the regulation of Tisza River). Magyar Állami Földtani Intézet Évi Jelentése 1945-47: 31-35 (in Hungarian).

Szeidovitz Gy, 2000. Érmelléki földrengések (Earthquakes in Érmelléki area). Magyar Geofizika 41: 78-84.

Țenu A, 1981. Zăcămintele de ape hipertermale din nord-vestul României (Thermal water storage in north-western Romania). Bucarest: 206pp (in Romanian).

Thamó-Bozsó E, Kercsmár Zs and Nádor A, 2002. Tectonic control on changes in sediment supply on Quaternary alluvial systems, Körös sub-basin, SE Hungary. In: Jones SJ and Frosrick LE, eds., Sediment Flux to Basin: Causes, Controls and Consequences. London, Geological Society, Special Publications 191: 37-53.

Thamó-Bozsó E, Murray AS, Nádor A, Magyari Á and Babinszki E, 2007. Investigation of river network evolution using luminescence dating and heavy mineral analysis of Late-Quaternary fluvial sands from the Great Hungarian Plain. Quaternary Geochronology 2(14): 168-173, DOI 10.1016/j.quageo.2006.05.012.

Thamó-Bozsó E and ÓKovács L, 2007. Evolution of Quaternary to modern fluvial network in the Mid-Hungarian Plain, indicated by heavy mineral distributions and statistical analysis of heavy mineral data. In: Mange MA and Wright D, eds., Heavy minerals in use. Development in sedimentology 58: 491-514.

Timár G, Telbisz T and Székely B, 2003. Ürtechnológia a digitális domborzati modellezésben: az SRTM adatbázis (Space technology in the digital elevation modelling: the SRTM database). Geodézia és Kartográfia 55(12): 11-15.

Timár G, Sümegi P and Horváth F, 2005. Late Quaternary dynamics of the Tisza River: evidence of climatic and tectonic controls. Tectonophysics 410: 97-110.

Újházy K, 2002. A dunavarsányi garmadabucka fejlődéstörténete radiometrikus kormeghatározások alapján (The evalution of the Dunavarsány sand dune according to radiometric dating results). Földtani Közlöny 132 special issue: 175-183 (in Hungarian).

Újházy K, Gábris Gy and Frechen M, 2003. Ages of periods of sand movement in Hungary determined through luminescence measurements. Quaternary International 111(1): 91-100, DOI 10.1016/S1040-6182(03)00017-X.

Urbancsek J, 1960. Az alföldi artézi kutak fajlagos vízhozama és abból levonható vízföldtani és ősföldrajzi következtetések (Specific water output of the artesian wells on the Hungarian Plain and hydrogeological and paleogeographical conclusions based on them). Hidrológiai Közlöny 40: 398-403 (in Hungarian).

Wintle A and Murray AS, 2006. A review of quartz optically stimulated luminescence characteristics and their relevance in single-aliquot regeneration dating protocols. Radiation Measurements 41(4): 369-391, DOI 10.1016/j.radmeas.2005.11.001. 